\title{
Processos Psicológicos e Sociais na Aprendizagem
}

\section{Boruchovitch, E.; \& Bzuneck, J.A. (orgs.) (2004). Aprendizagem: Processos Psicológicos e o Contexto Social na Escola., Petrópolis: Editora Vozes.}

A aprendizagem envolve uma integração de fatores contextuais e internos do aluno que podem tanto favorecer como afetar de maneira negativa o processo de aprender. Assim, o presente livro apresenta uma coletânea de temas da Psicologia Educacional com o objetivo de analisar e discutir os processos psicológicos e sociais na aprendizagem, dentro de uma perspectiva cognitiva e sociocognitiva. Fornece dados de pesquisas, bem como uma vasta revisão de literatura a respeito do assunto, tratando-se, portanto, de uma referência bastante contemporânea e valiosa para aqueles que estão envolvidos na educação. No livro, os aspectos internos do indivíduo são privilegiados e o estudante deixa de ser visto como passivo e receptor de informações e passa a ter uma participação mais ativa no próprio processo de aprendizagem.

De uma forma geral, o livro traz a tona a discussão de que a escola não é apenas um ambiente para a aprendizagem formal, mas também uma rica fonte de experiências emocionais e sociais para os alunos. A partir dessa idéia, o conjunto de capítulos aborda tanto os aspectos intra-individuais na aprendizagem como variáveis sociais do contexto escolar.

O livro reúne nove capítulos que estão organizados em duas partes, sendo que os cincos primeiros capítulos discutem importantes aspectos relacionados aos processos intra-individuais na aprendizagem, enquanto a segunda se concentra na análise de fatores relacionados ao contexto social que exercem forte influência no processo de aprendizagem. Embora os contextos social e individual estejam divididos no livro, vale ressaltar que se tratam de aspectos estreitamente relacionados e essa inter-relação é cuidadosamente contemplada na obra.

No primeiro capítulo, a teoria do processamento da informação é discutida considerando a literatura na área. O desenvolvimento histórico, bem como todo o processo pelo qual a informação se processa são detalhadamente descritos por José Aloyseo Bzuneck.

Evely Boruchovitch descreve, no capítulo 2, o conceito de auto-regulação de acordo com as diferentes abordagens teóricas, com atenção especial à teoria do processamento da informação. Além disso, a autora discute a auto-regulação nas faixas etárias, particularmente entre as crianças da pré-escola e do ensino fundamental, enfatizando a importância da aprendizagem auto-regulada desde o início da escolarização. A autora aponta algumas sugestões para a promoção da aprendizagem autoregulada que podem ser empregadas pelos educadores.

No capítulo 3, Maria Aparecida Gomes e Evely Boruchovitch exploram as possibilidades do uso de jogos segundo o referencial teórico da psicologia cognitiva, baseada no processamento da informação. Primeiramente, as autoras discutem o emprego de jogos como um recurso de diagnóstico, bem como de intervenção psicopedagógica. Em seguida as autoras focalizam a utilização do jogo para uma aprendizagem mais consciente e auto-regulada.

A importância da compreensão de leitura em universitários é analisada no capítulo 4 pelas autoras Acácia Aparecida Angeli dos Santos e Katya Luciane de Oliveira. Formas de avaliação da compreensão de leitura e suas consequiências na aprendizagem dos estudantes de ensino superior são discutidas pelas autoras. Analisam o importante papel das universidades no desenvolvimento de bons leitores.

As dificuldades de aprendizagem são apontadas pela literatura como condições adversas que podem prejudicar o desenvolvimento infantil. Sob a perspectiva de uma abordagem desenvolvimentista Sonia Regina Loureiro e Paula Cristina Medeiros discutem, no capítulo 5 que a dificuldade de aprendizagem, quando presente no período inicial da escolarização pode favorecer a vulnerabilidade ao desenvolvimento infantil, sendo necessário a 
elaboração de programas de suporte visando o enfrentamento de tais situações consideradas críticas para o desenvolvimento. Dessa forma, conceitos como vulnerabilidade, resiliência e fatores de proteção são analisados neste capítulo. Em um segundo momento deste capítulo, aspectos relacionados as dificuldades de aprendizagem como as crenças de auto-eficácia são avaliados. A partir disso, as autoras relatam também os benefícios de uma intervenção psicopedagógica realizada em pequenos grupos e de curta duração com crianças brasileiras que apresentam dificuldades de aprendizagem.

Assim como os processos internos ao indivíduo são extremamente relevantes para uma aprendizagem de qualidade, as interações sociais têm sido apontada pela literatura como um fator essencial para o aprender. A segunda parte do livro é composta pelos quatro capítulos finais, sendo que nos capítulos 6 e 7 são focalizadas as interações sociais enquanto processo facilitador do desenvolvimento humano, e mais especificamente, da aprendizagem. Sueli Edi Rufini Guimarães, no capítulo 6 , inicia o texto com aspectos teóricos relativos à necessidade de pertencer e de estabelecer vínculos para o desenvolvimento humano. Alguns resultados de pesquisas sobre o tema são relatados e discute algumas alternativas para propiciar um ambiente escolar seguro e facilitador de interações sociais positivas.

O importante papel desempenhado pela escola no desenvolvimento social dos estudantes é apresentado por Carolina Lisboa e Silvia Helena Koller no capítulo 7. As autoras discutem que o papel da escola transcende a aprendizagem de conteúdos, devendo a escola ser também um contexto que favoreça o desenvolvimento emocional e social de seus alunos. Temas como amizade, vitimização e rejeição são abordados neste capítulo.

No capítulo 8, Fermino Fernandes Sisto aborda, dentro de uma vertente construtivista piagetiana, as relações entre relacionamento social, aprendizagem e desenvolvimento social. $\mathrm{O}$ autor apresenta resultados de um conjunto de pesquisas, principalmente relacionados ao papel da intervenção psicoeducacional.

O livro é finalizado com o capítulo 9 de José Aloyseo Bzuneck e Sueli Edi Rufini Guimarães, no qual são apontadas a competitividade no contexto escolar e as crenças que os professores possuem em relação a competição. Muitas vezes, a competição é vista como uma estratégia motivadora, no entanto as conseqüências negativas dessa prática são apresentadas neste capítulo.

Percebe-se, durante toda a obra, a expectativa de se otimizar a aprendizagem humana, valorizando o desenvolvimento psicológico e social do aluno, sendo este um dos importantes papeis da escola. Dessa forma, acredita-se que o presente livro possa contribuir para aqueles que se preocupam com a aprendizagem do aluno e mais especificamente, valorizam o indivíduo enquanto uma pessoa única, sendo, portanto recomendado para professores, educadores e pesquisadores da área da educação e psicologia. 